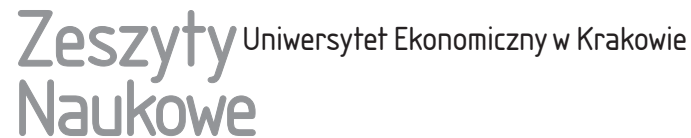

Joanna Wyrobek

Katedra Finansów Przedsiębiorstw

Uniwersytet Ekonomiczny w Krakowie

\section{Zmiany wydajności pracy i kosztów pracy w Polsce a konkurencyjność gospodarki Polski}

\section{Streszczenie}

Celem artykułu było prześledzenie zmian wydajności pracy i kosztów pracy w świetle ich potencjalnego wpływu na pozycję konkurencyjną Polski w okresie 2004-2012. Podjęto próbę odpowiedzi na następujące pytania: jak szybko zmieniała się wydajność pracy w Polsce w ujęciu realnym, jakie było tempo zmian jednostkowego kosztu pracy w ujęciu realnym, czy realne zmiany wydajności pracy były przynajmniej tak samo wysokie jak tempo wzrostu jednostkowego kosztu pracy (co podnosiłoby atrakcyjność polskiej gospodarki dla inwestorów zagranicznych poszukujących lokalizacji dla swoich zakładów produkcyjnych) oraz jaka jest pozycja wydajności pracy i kosztu pracy w Polsce w stosunku do innych gospodarek światowych. Szczególny nacisk położono na porównanie Polski do Czech, Słowacji i Węgier jako krajów o podobnym stopniu rozwoju gospodarczego i warunkach prowadzenia działalności gospodarczej, ale także innych krajów świata.

Z badań wynika, że wzrost wydajności pracy w Polsce był wyższy niż wzrost jednostkowego kosztu pracy, co powinno mieć pozytywny wpływ na pozycję konkurencyjną Polski, a także że Polska nie należy już do krajów o najniższych wynagrodzeniach, co oznacza, że obecna konkurencyjność nie opiera się wyłącznie na taniej sile roboczej, ale na kombinacji niskich kosztów pracy i stosunkowo wysokiej wydajności pracy.

Słowa kluczowe: wydajność siły roboczej, koszt jednostkowy siły roboczej, konkurencyjność, wynagrodzenia, inwestycje międzynarodowe. 


\section{Rola wydajności pracy i kosztów pracy w ocenie konkurencyjności gospodarki}

Konkurencyjność gospodarki zależy od bardzo wielu czynników i nie istnieje jeden kompletny zbiór jej determinant. Za pewną wskazówkę może jednak służyć budowa indeksów mierzących konkurencyjność krajów, w tym indeksu konkurencyjności gospodarek publikowanego przez Światowe Forum Ekonomiczne (World Economic Forum). Za najważniejsze determinanty uważa się tam: 1) jakość instytucji publicznych i 2) prywatnych (m.in. ochronę praw własności, poziom etyki i korupcji, niezależność instytucji rządowych i brak faworytyzmu, efektywność rządu, bezpieczeństwo wewnętrzne i zewnętrzne, poziom kontroli i nadzoru przedsiębiorstw), 3) jakość infrastruktury (m.in. transportowej, telekomunikacyjnej, energetycznej), 4) sytuację makroekonomiczną, 5) poziom opieki zdrowotnej i 6) edukacji, 7) poziom efektywności rynku towarów, 8) efektywność rynku pracy, 9) rozwój rynku finansowego, 10) poziom technologiczny kraju, 11) wielkość rynku 12) poziom infrastruktury biznesowej na rynku wewnętrznym, 13) innowacyjność gospodarki.

Na efektywność rynku pracy składają się takie elementy, jak: elastyczność form zatrudnienia, poziom wynagrodzeń i wydajność pracy, równouprawnienie kobiet, skuteczność wykorzystania talentów, łatwość zwolnienia pracowników, poziom opodatkowania wynagrodzeń, rzetelność kadry kierowniczej, atrakcyjność kraju w ściąganiu utalentowanych pracowników. Jednym z głównych czynników wpływających na napływ nowych inwestycji i odpływ istniejących są koszty pracy i jej wydajność [Bossak 2001, Jasiński 2001, Misala 2001].

Celem niniejszej publikacji jest prześledzenie zmian wydajności pracy i kosztów pracy w świetle ich potencjalnego wpływu na pozycję konkurencyjną Polski w okresie 2004-2012. Okres wybrany do badań wynikał z dostępności danych, które Bank Światowy publikuje z dużym opóźnieniem.

\section{Wydajność i koszty pracy w świetle literatury przedmiotu}

Jedną z cech charakterystycznych współczesnej gospodarki jest nasilający się proces globalizacji, a także bardzo wysoki stopień i szybkość przepływu informacji [Rachwał i in. 2008, s. 1]. Teoretycznie, jak to można próbować (nieco błędnie) wnioskować z bardzo znanego twierdzenia Heckschera-Ohlina-Samuelsona [Blaug 1992, s. 286] globalizacja doprowadzi do wyrównania cen produktów i czynników produkcji (w tym wynagrodzeń) w różnych krajach, nawet jeżeli nie będzie mobilności czynników produkcji. Dotyczy to jednak (o ile w ogóle model ten można rozszerzać na wiele krajów i wiele czynników produkcji (por. [Rybiński 
2007, s. 32]) bardzo długiego okresu. W krótkim okresie teoria ekonomii przewiduje jednak występowanie różnic w opisanych cenach, jak to czyni na przykład bardzo znana teoria Balassy-Samuelsona [Samuelson 1994, s. 201-226]. Zgodnie ze wspomnianą teorią różnice w technologii (w efekcie także w wydajności pracy) pomiędzy krajami, dotyczące szczególnie sektora dóbr typu nontradables (pozostających poza obszarem handlu międzynarodowego), prowadzą do różnic w cenach (w konsekwencji także w wynagrodzeniach) pomiędzy krajami mniej i bardziej rozwiniętymi gospodarczo. W krótkim okresie i przy nierównym zaawansowaniu technologicznym nie dochodzi do pełnego wyrównania cen produktów i czynników produkcji. Kraje zaawansowane technicznie posiadają wyższą wydajność pracy, ale i wyższe koszty pracy, a kraje mniej zaawansowane technicznie będą wykazywały niższą wydajność pracy i niższe koszty pracy. Opisany proces stwarza pole do konkurowania pomiędzy krajami o nowe inwestycje i daje podstawy teoretyczne do oczekiwania różnic w ich poziomie konkurencyjności.

Wspomniane już wcześniej otwarcie granic pomiędzy krajami na przepływy towarowe i kapitałowe połączone $\mathrm{z}$ doskonałym dostępem do informacji powodują, że zmiany w konkurencyjności krajów bardzo szybko wpływają na kierunki przepływu kapitału i inwestycji. Szczególne znaczenie ma atrakcyjność warunków gospodarowania dla przedsiębiorstw produkcyjnych [Domański 1997, Rydz i Szymańska 2006, Zioło 2008], które tworzą różnego rodzaju powiązania przestrzenno-produkcyjne i dlatego są szczególnie cenne dla gospodarki danego $\mathrm{kraju}^{1}$. Wyrazem tej atrakcyjności są procesy przenoszenia przedsiębiorstw lub ich części do innych krajów oraz nasilenie koncentracji firm w danym regionie. Zakładając przy tym (za [Rachwał i in. 2008, s. 1]), że w gospodarce opartej na wiedzy podstawową rolę odgrywają zasoby siły roboczej, można przyjąć, że jednym z ważnych kryteriów konkurencyjności danego kraju czy regionu dla relokacji i inwestycji będą właściwości rynku pracy oraz wydajność siły roboczej [Bossak 2001, Jasiński 2001, Misala 2001].

O pozytywnych skutkach nowych inwestycji w danym regionie napisano bardzo dużo, w skrócie korzyści z nich wynikające to nie tylko bezpośredni wzrost zatrudnienia i PKB, ale także szereg efektów mnożnikowych uzyskiwanych dzięki zatrudnianiu podwykonawców z danego regionu, generowaniu dodatkowego popytu, wpływaniu na poprawę koniunktury w danym regionie [Garnick 1970, Wpływ inwestorów... 2004, Wiedermann 2007].

\footnotetext{
${ }^{1}$ Nie można jednak zapominać o ryzyku pogorszenia warunków gospodarowania przedsiębiorstw w wyniku występowania wypadków losowych generujących szkody. O metodach zarządzania ryzykiem przedsiębiorstw, w szczególności poprzez ubezpieczenia, pisze G. Strupczewski [2013].
} 
Przy porównywaniu wydajności pracy i jednostkowego kosztu pracy warto pamiętać, że są ze sobą powiązane i dlatego zwykle niskiemu jednostkowemu kosztowi pracy towarzyszy stosunkowo niska wydajność pracy. Dzieje się tak dlatego, że tam, gdzie jednostkowe koszty pracy są wysokie stosuje się zwykle bardziej zaawansowane technologie podnoszące wydajność pracy, a tam gdzie jednostkowe koszty są niskie, bardzo często technologie są mniej zaawansowane, a czasami nawet nie opłaca się wprowadzać bardziej zaawansowanych, ale i kosztowniejszych rozwiązań [Rachwał $i$ in. 2008, s. 5].

Kraje Europy Środkowo-Centralnej czy inne gospodarki rozwijające się charakteryzują się zwykle niską wydajnością pracy i niskimi kosztami pracy, a kraje Europy Zachodniej czy Ameryki Północnej charakteryzują się zwykle wysokimi kosztami pracy i wysoką wydajnością pracy. Wyraźne rozróżnienie warunków pomiędzy krajami rozwiniętymi i rozwijającymi się zwykle skutkuje migracją produkcji pracochłonnej do krajów rozwijających się, a produkcji wymagającej wysokiej technologii do krajów rozwiniętych (jakkolwiek w krajach rozwijających się także mogą występować lub zostać stworzone warunki sprzyjające firmom wysokich technologii).

Podział na kraje z tanią i drogą siłą roboczą i zaawansowaną lub niezaawansowaną technologią nie jest stały i niezmienny. Każdego dnia i w każdym kraju dokonują się zmiany przebiegu procesów gospodarczych, co między innymi wpływa także na wydajność pracy czy też produktywność (wydajność pracy i produktywność pracy to synonimy [Kozioł 2004, s. 65]) i koszt pracy.

\section{Zmiany jednostkowego kosztu pracy i wydajności pracy w Polsce na tle wybranych krajów świata - wyniki własnych badań}

W celu analizy zmian jednostkowego kosztu pracy i wydajności siły roboczej w Polsce wykorzystano dwa zbiory danych. Pierwszy zbiór pochodził z bazy OECD (Organizacji Współpracy Gospodarczej i Rozwoju) i zawierał dane dla krajów członków OECD. Drugi zbiór danych pochodził z bazy IMD World Competitiveness Online 1995-2014 i częściowo obejmował inne kraje niż pierwsze źródło (baza OECD). Grupa krajów i wyniki obliczeń wykonanych osobno dla dwóch wspomnianych źródeł są odmienne, co wynika z innego sposobu pomiaru wydajności pracy. Pomimo częściowych niezgodności wyników (co się wiąże z inną metodą pomiaru wydajności pracy) do badań użyto obydwu zbiorów danych, aby uzyskać pełniejszy obraz sytuacji Polski i porównywalność z większą grupą krajów na świecie. 
W obydwu bazach danych (OECD i IMD) jednostkowe koszty pracy i ich zmiana zostały obliczone jako zmiana rok do roku wartości jednostkowych kosztów robocizny wyrażonych w dolarach amerykańskich. Jednostkowe koszty robocizny zostały obliczone jako iloraz całkowitych kosztów siły roboczej w danym kraju podzielonych przez całkowitą wartość dodaną wytworzoną $\mathrm{w}$ danym roku w danym kraju, przy czym wartość dodana była wyrażona w stałych cenach (w dolarach amerykańskich). Taki miernik pokazuje jak dużo kosztów robocizny w danej gospodarce wymaga wytworzenie produktu wartego 1 dolara. Im ta wartość jest niższa, tym bardziej konkurencyjna jest dana gospodarka pod względem kosztów pracy.

Wydajność siły roboczej w bazie OECD została obliczona na podstawie PKB denominowane $w$ dolarach amerykańskich w stałych cenach. W bazie IMD World Competitiveness Online 1995-2014 (w skrócie, w bazie IMD) wydajność siły roboczej obliczono za pomocą PKB wyrażonego w dolarach amerykańskich według parytetu siły nabywczej (PKB dostosowany do zmian parytetu siły nabywczej).

Dla bazy OECD wydajność siły roboczej obliczono jako iloraz wspomnianego PKB (w stałych cenach w USD) podzielonego przez liczbę godzin przepracowanych w danej gospodarce (w danym kraju). Dla bazy IMD miarę PKB (według parytetu siły nabywczej w USD) podzielono przez liczbę pracujących osób w danym kraju i potem przez średnią liczbę godzin przepracowanych przez pracownika w danym kraju [Koszty pracy 2013; OECD: Labour Costs 2013]. Uzyskane wyniki przedstawiono na rys. 1 i 2.

Jak to wynika z rys. 1 i 2 Polska od 2004 do 2012 r. poprawiła znacząco wydajność siły roboczej: skumulowany wzrost wydajności siły roboczej mierzonej za pomocą realnego PKB wynosił 77,59\%, a dla wydajności siły roboczej mierzonej za pomocą PKB według PPP wynosił 31,4\%. Spośród badanych krajów jedynie: Estonia, Rumunia, Słowacja i Słowenia uzyskały porównywalny wynik. Większość gospodarek rozwiniętych podnosiła wydajność znacznie wolniej, zwykle osiągając połowę wzrostu, jaki uzyskała Polska. Nawet jeżeli wydajność siły roboczej dla Polski jest wciąż niska w porównaniu z krajami rozwiniętymi, różnica pomiędzy Polską a krajami zachodnimi maleje.

Jak to pokazano na rys. 1, wzrostowi wydajności pracy towarzyszył 43-procentowy wzrost wynagrodzeń (dla wynagrodzeń w walucie krajowej i cenach bieżących, dla okresu 2004-2012). Jednak po wyłączeniu inflacji i po korekcie o parytet siły nabywczej w skrócie PPP) oraz przeliczeniu na dolary amerykańskie, w okresie 2004-2012 średnie wynagrodzenie roczne w Polsce wzrosło z 19037 USD na rok do 21110 USD na rok, co daje wzrost o 11\% dla całego 


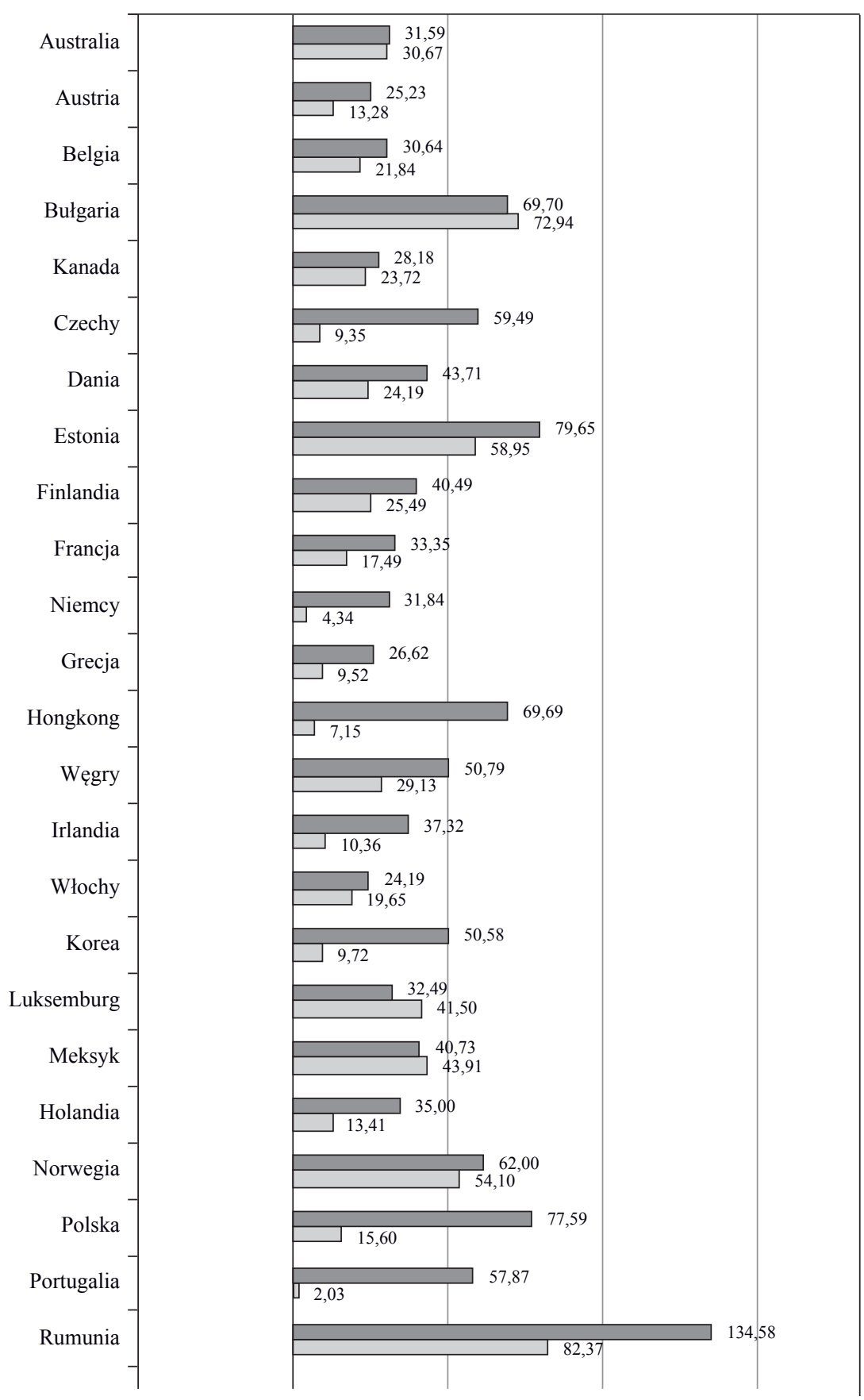




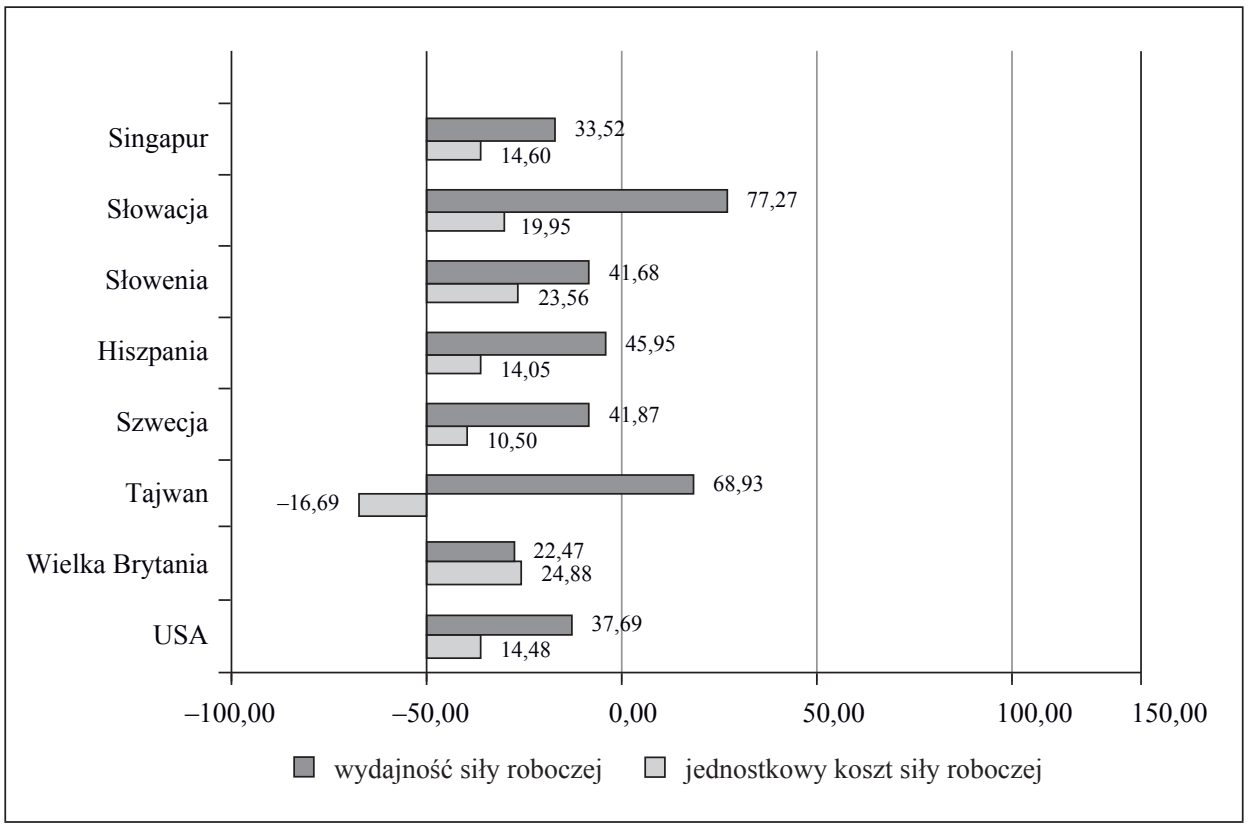

Rys. 1. Dynamika wydajności siły roboczej i jednostkowego kosztu pracy w okresie 2004-2012 (w \%)

Źródło: IMD World Competitiveness Online 1995-2014, baza dostępna w Bibliotece Narodowego Banku Polskiego (dostęp: 10.07.2015).

okresu 2004-2012. Porównując zmianę wydajności pracy i realnego kosztu pracy (PPP), można zauważyć, że wynagrodzenia rosły wolniej niż wydajność.

W okresie 2004-2012 nastąpił wzrost jednostkowych kosztów pracy. W zależności od bazy danych wynosił on albo 14,44\% albo $15,6 \%$ (por. rys. 1 i rys. 2).

Wolniejszy wzrost jednostkowych kosztów pracy można było zaobserwować w: Austrii, Czechach, Niemczech, Grecji, Holandii, Portugalii, Singapurze, Hiszpanii, Szwecji, Tajwanie i USA. Obliczając różnicę pomiędzy skumulowanym przyrostem wydajności pracy i skumulowanym przyrostem jednostkowego kosztu pracy (skumulowanym, tj. obliczonym dla całego okresu 2004-2012), Polska znajduje się na trzecim miejscu po Japonii i Hongkongu (obliczenia wykazały różnicę pomiędzy procentową zmianą wydajności pracy oraz procentową zmianą jednostkowego kosztu pracy - są to różnice pomiędzy wielkościami dla danego kraju liczonymi osobno dla rys. 1 i osobno dla rys. 2, na przykład dla Polski jest to na rys. 1: $77,59 \%-15,60 \%=61,99$ p.p. a na rys. $2: 31,4 \%-14,44 \%=16,96$ p.p.).

Aby potwierdzić długookresową poprawę sytuacji gospodarki polskiej pod względem relacji wydajności do kosztów pracy, zbadano na koniec jeszcze 


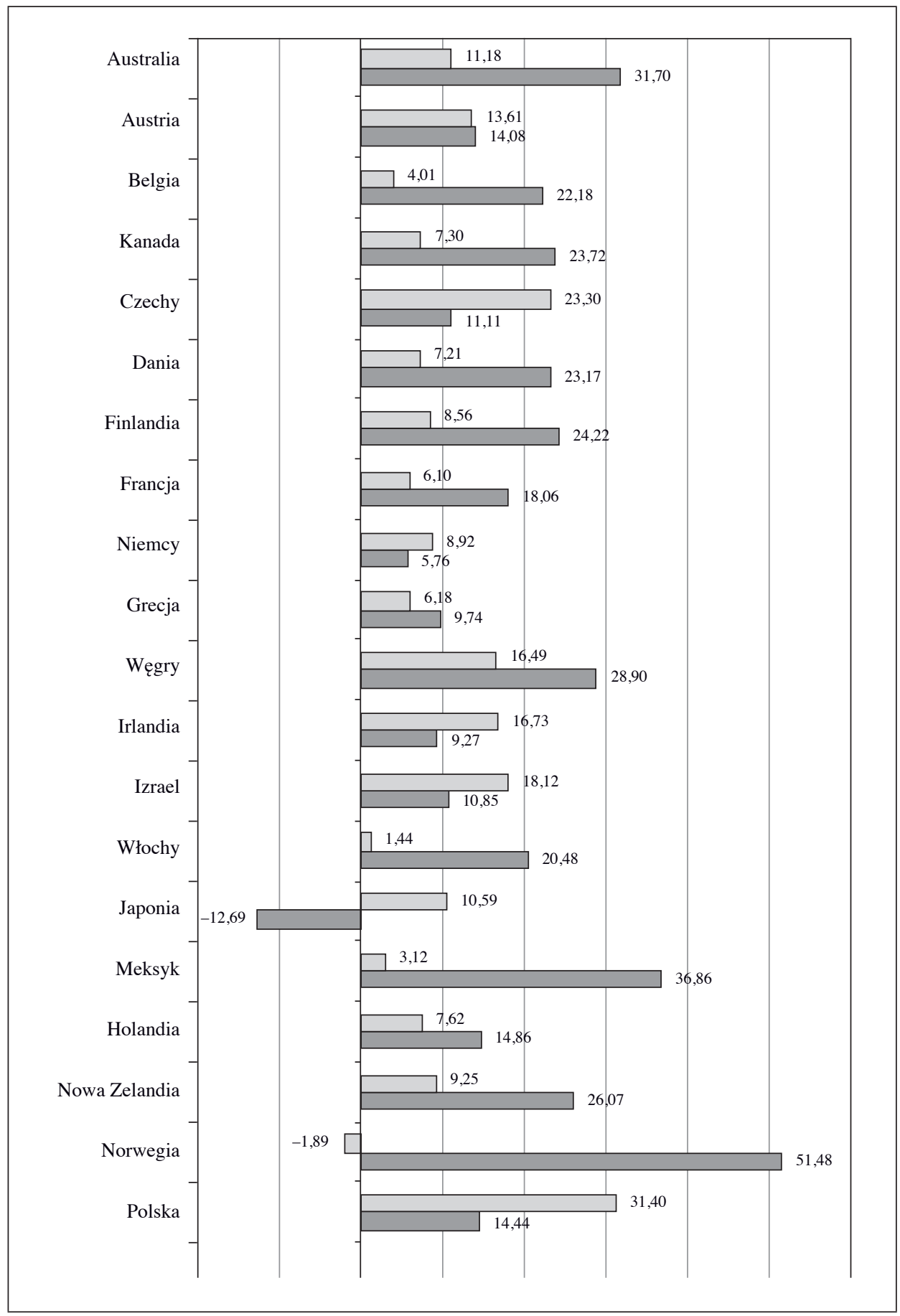




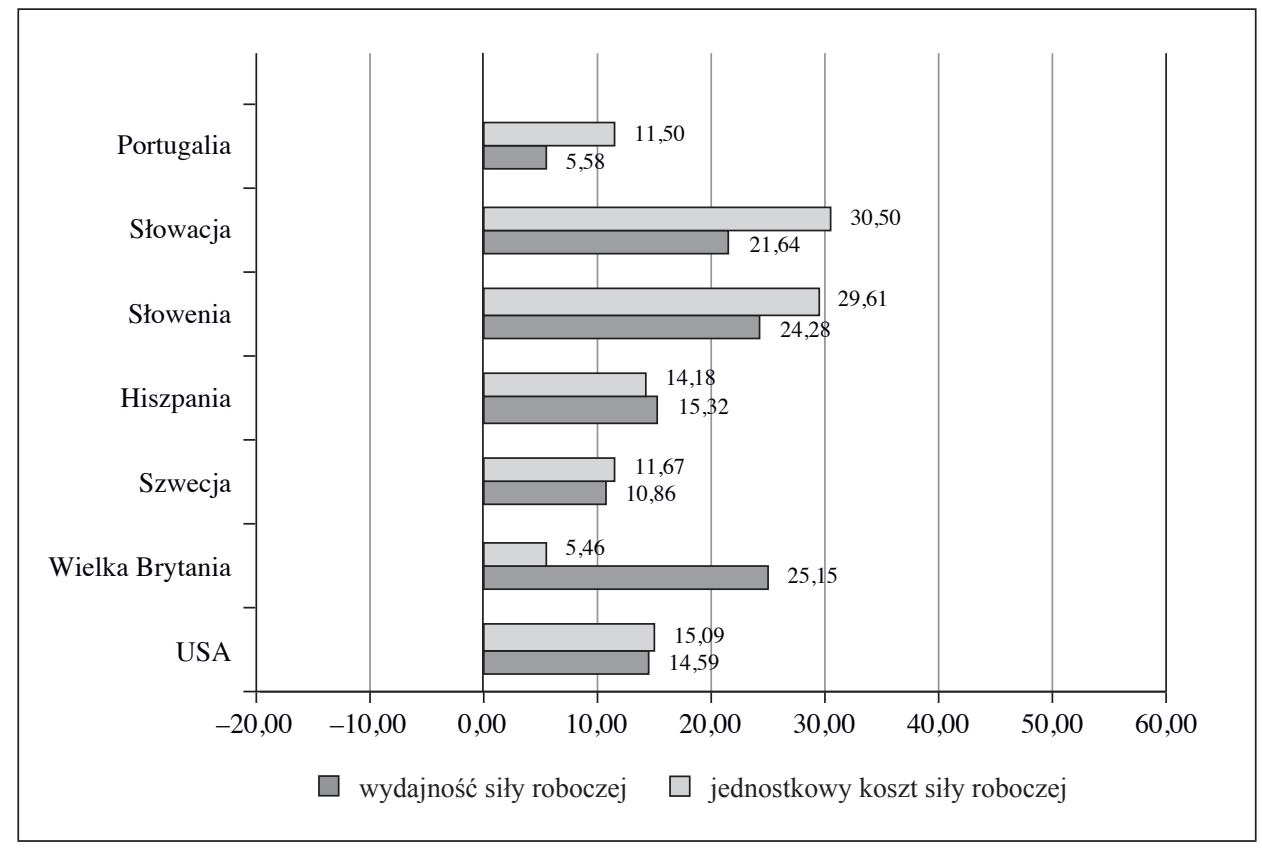

Rys. 2. Dynamika wydajności siły roboczej i jednostkowego kosztu pracy w okresie 2004-2012 (w \%)

Źródło: wydajność pracy: http://stats.oecd.org/index.aspx?datasetcode=level; jednostkowy koszt pracy: http://stats.oecd.org/index.aspx?queryname=426 (dostęp: 11.07.2015).

dłuższy szereg czasowy, a mianowicie lata od 1999 do 2012. W dłuższym okresie (lata 1999-2012, rys. 3, taki długi szereg czasowy był tylko dostępny dla bazy OECD) można zauważyć, że Polska jest ponownie jednym z liderów klasyfikacji, gdyż zakumulowana poprawa wydajności oraz różnica pomiędzy zmianą wydajności a zmianą jednostkowego kosztu robocizny były najwyższe $(72,1 \%-26,77 \%=$ $=45,33$ p.p.). Był to najlepszy wynik wśród wszystkich krajów objętych obliczeniami.

Warto na koniec przyjrzeć się zmianom składowej powyższej różnicy (jednostkowego kosztu pracy), jakim jest średnie wynagrodzenie. Średnie wynagrodzenie w Polsce (wyrażone w dolarach amerykańskich dostosowanych do PPP) wzrosło z 17752 USD w 1999 r. do 21110 w 2012 r., co oznacza wzrost o prawie 19\% (tabela 1). 


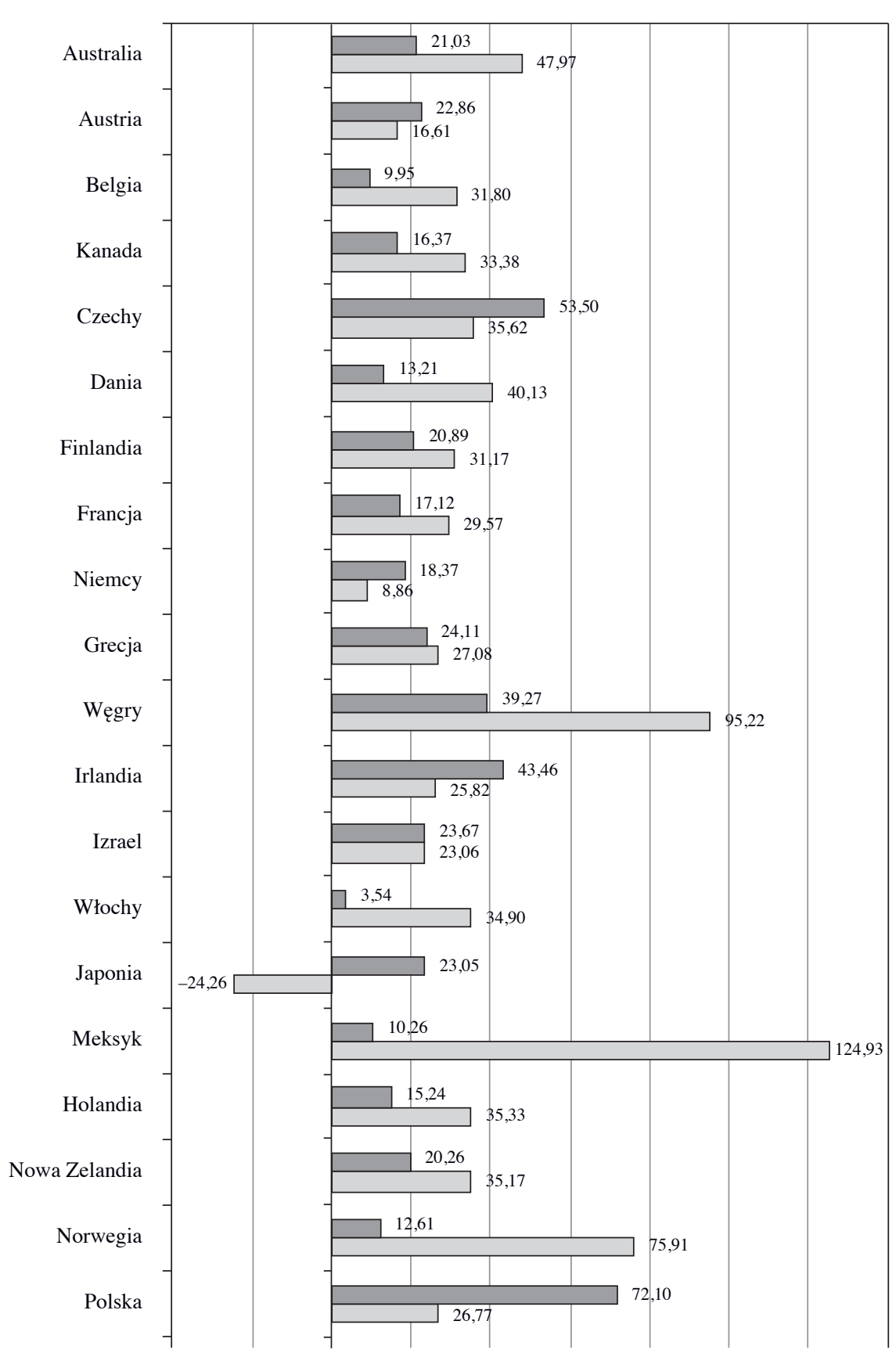




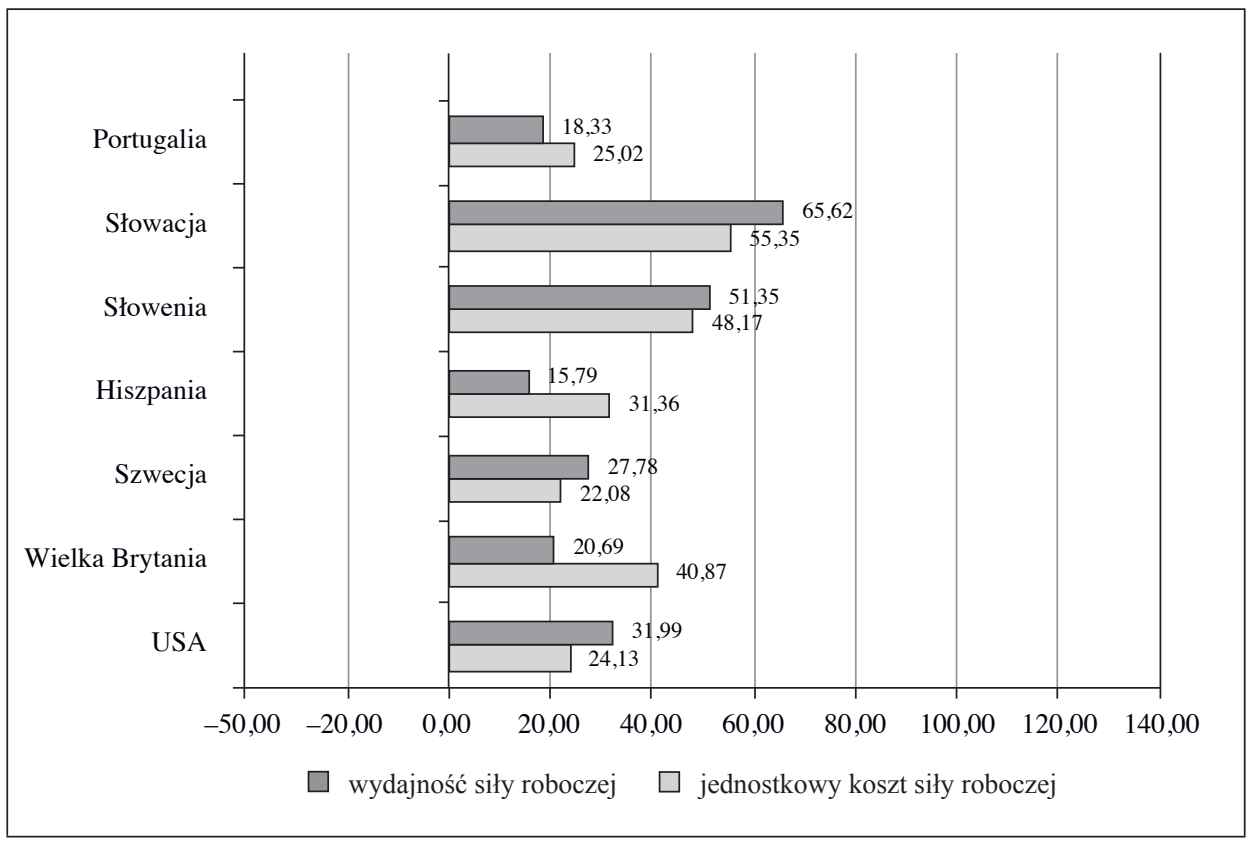

Rys. 3. Dynamika wydajności siły roboczej i jednostkowego kosztu pracy w okresie 1999-2012 (w \%)

Źródło: jak do rys. 2.

Tabela 1. Dynamika średniego wynagrodzenia (dostosowanego do PPP) w krajach OECD, lata 1999-2012

\begin{tabular}{|l|r|r|r|r|r|r|r|r|r|r|}
\hline \multirow{2}{*}{$\begin{array}{l}\text { Wyszcze- } \\
\text { gólnienie }\end{array}$} & \multicolumn{4}{|c|}{ Ceny stałe (USD), PPP } & \multicolumn{4}{|c|}{ Ceny zmienne waluta krajowa } \\
\cline { 2 - 12 } & $\begin{array}{r}1999- \\
2012\end{array}$ & $\begin{array}{c}2004- \\
2012\end{array}$ & 1999 & 2004 & 2012 & $\begin{array}{r}1999- \\
2012\end{array}$ & $\begin{array}{r}2004- \\
2012\end{array}$ & 1999 & 2004 & 2012 \\
\hline Australia & $17,09 \%$ & $10,56 \%$ & 42407 & 44911 & 49655 & $65 \%$ & $38 \%$ & 45560 & 54298 & 75138 \\
\hline Austria & $8,65 \%$ & $3,49 \%$ & 41088 & 43139 & 44644 & $40 \%$ & $24 \%$ & 27296 & 30870 & 38273 \\
\hline Belgia & $5,99 \%$ & $0,99 \%$ & 44804 & 47023 & 47487 & $37 \%$ & $21 \%$ & 30277 & 34203 & 41536 \\
\hline Czechy & $51,90 \%$ & $16,57 \%$ & 13487 & 17575 & 20487 & $92 \%$ & $32 \%$ & 158127 & 229607 & 303229 \\
\hline Dania & $15,42 \%$ & $5,92 \%$ & 39015 & 42513 & 45031 & $53 \%$ & $29 \%$ & 263647 & 312556 & 402904 \\
\hline Estonia & $71,66 \%$ & $29,30 \%$ & 10613 & 14093 & 18222 & $209 \%$ & $82 \%$ & 3710 & 6315 & 11477 \\
\hline Finlandia & $24,63 \%$ & $11,73 \%$ & 31464 & 35099 & 39215 & $55 \%$ & $30 \%$ & 25187 & 29977 & 39100 \\
\hline Francja & $14,62 \%$ & $7,26 \%$ & 34547 & 36921 & 39600 & $42 \%$ & $22 \%$ & 24839 & 28891 & 35151 \\
\hline Grecja & $1,67 \%$ & $-11,10 \%$ & 25634 & 29317 & 26063 & $46 \%$ & $9 \%$ & 13597 & 18240 & 19898 \\
\hline Hiszpania & $2,24 \%$ & $6,52 \%$ & 33769 & 32413 & 34525 & $46 \%$ & $27 \%$ & 18238 & 20907 & 26584 \\
\hline Holandia & $8,44 \%$ & $3,41 \%$ & 43016 & 45106 & 46646 & $47 \%$ & $20 \%$ & 30148 & 36831 & 44232 \\
\hline Irlandia & $32,49 \%$ & $19,08 \%$ & 38920 & 43301 & 51565 & $67 \%$ & $23 \%$ & 29328 & 39979 & 49082 \\
\hline
\end{tabular}


cd. tabeli 1

\begin{tabular}{|c|c|c|c|c|c|c|c|c|c|c|}
\hline \multirow{2}{*}{$\begin{array}{l}\text { Wyszcze- } \\
\text { gólnienie }\end{array}$} & \multicolumn{5}{|c|}{ Ceny stałe (USD), PPP } & \multicolumn{5}{|c|}{ Ceny zmienne waluta krajowa } \\
\hline & $\begin{array}{c}1999- \\
2012\end{array}$ & $\begin{array}{c}2004- \\
2012\end{array}$ & 1999 & 2004 & 2012 & $\begin{array}{c}1999- \\
2012\end{array}$ & \begin{tabular}{|c|}
$2004-$ \\
2012
\end{tabular} & 1999 & 2004 & 2012 \\
\hline Japonia & $-0,11 \%$ & $1,38 \%$ & 34176 & 33673 & 34138 & $-12 \%$ & $-5 \%$ & 4529917 & 4236132 & 4004927 \\
\hline Kanada & $21,71 \%$ & $16,72 \%$ & 37401 & 38998 & 45521 & $51 \%$ & $32 \%$ & 38987 & 44566 & 58881 \\
\hline Korea Płd. & $23,71 \%$ & $10,12 \%$ & 29713 & 33379 & 36757 & $79 \%$ & $33 \%$ & 17966424 & 24082694 & 32079004 \\
\hline $\begin{array}{l}\text { Luksem- } \\
\text { burg }\end{array}$ & $10,25 \%$ & $3,68 \%$ & 47747 & 50770 & 52639 & $47 \%$ & $24 \%$ & 38348 & 45673 & 56523 \\
\hline Niemcy & $7,27 \%$ & $3,90 \%$ & 39267 & 40541 & 42121 & $103 \%$ & $36 \%$ & 56269 & 83839 & 114152 \\
\hline Norwegia & $38,29 \%$ & $21,84 \%$ & 33562 & 38092 & 46412 & $26 \%$ & $16 \%$ & 27633 & 30062 & 34879 \\
\hline Polska & $18,92 \%$ & $10,89 \%$ & 17752 & 19037 & 21110 & $78 \%$ & $43 \%$ & 267068 & 333190 & 476236 \\
\hline Portugalia & $1,07 \%$ & $-1,64 \%$ & 22853 & 23483 & 23098 & $81 \%$ & $39 \%$ & 23796 & 30970 & 43019 \\
\hline Słowacja & $49,24 \%$ & $21,42 \%$ & 13542 & 16645 & 20210 & $33 \%$ & $12 \%$ & 11578 & 13765 & 15422 \\
\hline Szwajcaria & $12,54 \%$ & $7,29 \%$ & 47331 & 49648 & 53265 & $138 \%$ & $56 \%$ & 4812 & 7334 & 11475 \\
\hline Szwecja & $23,98 \%$ & $14,49 \%$ & 31854 & 34495 & 39494 & $23 \%$ & $14 \%$ & 68989 & 74664 & 84866 \\
\hline USA & $13,13 \%$ & $4,50 \%$ & 48659 & 52677 & 55048 & $51 \%$ & $30 \%$ & 241393 & 280732 & 364765 \\
\hline Węgry & $35,97 \%$ & $-1,06 \%$ & 14954 & 20550 & 20332 & $50 \%$ & $25 \%$ & 36771 & 44074 & 55311 \\
\hline $\begin{array}{l}\text { Wielka } \\
\text { Brytania }\end{array}$ & $13,28 \%$ & $-1,32 \%$ & 39037 & 44813 & 44223 & $173 \%$ & $42 \%$ & 1088680 & 2083106 & 2967298 \\
\hline Włochy & $0,11 \%$ & $-0,82 \%$ & 33813 & 34130 & 33849 & $50 \%$ & $23 \%$ & 21201 & 25964 & 31850 \\
\hline
\end{tabular}

Źródło: jak do rys. 2.

\section{Podsumowanie}

Celem niniejszego artykułu była ocena zmian wydajności siły roboczej i jednostkowych kosztów robocizny w Polsce na tle innych krajów świata pod kątem oceny czy w okresie 2004-2012 Polska podtrzymała lub poprawiła swoją konkurencyjność ze względu na wydajność siły roboczej i jednostkowy koszt pracy.

Na podstawie przedstawionych danych można zauważyć dwa zjawiska: jedno pozytywne, a drugie potencjalnie negatywne. Pozytywnym zjawiskiem jest szybszy wzrost wydajności pracy niż jednostkowego kosztu pracy, co sugerowałoby polepszenie konkurencyjnej pozycji Polski.

Niekorzystne jest to, że w badanym okresie doszło do wzrostu wynagrodzeń (z punktu widzenia pracowników jest to zjawisko pozytywne, ale z punktu widzenia potencjalnych inwestycji zagranicznych i kosztów przedsiębiorstw - potencjalnie negatywne). W analizowanym okresie 1999-2012 odnotowano 19-procentowy skumulowany wzrost średniego wynagrodzenia (dostosowa- 
nego do PPP), co oznacza roczny wzrost o $1,35 \%$ (lub o 1,46 p.p.). W okresie 1999-2012 wzrosły również jednostkowe koszty pracy o 26,7\%, co daje roczny wzrost o $1,84 \%$. Pomimo poprawy relacji pomiędzy jednostkowym kosztem pracy a wydajnością pracy może to działać na niekorzyść Polski, gdyż przy produkcji prostych wyrobów największe znaczenie mają jednostkowe koszty pracy, a nie wydajność pracy będąca pochodną technologii (dla danego rodzaju produkcji technologia może nie mieć znaczenia, a produkcja może opierać się głównie na bezpośredniej fizycznej pracy ludzkiej bez wykorzystania maszyn i technologii). Pytanie, jakie można w tych warunkach zadać, to dla kogo obecna relacja wydajności pracy i jednostkowego kosztu pracy będzie atrakcyjna, czyli jaka działalność gospodarcza wymaga przeciętnej technologii i stosunkowo niskiego (w relacji do wydajności pracy) jednostkowego kosztu pracy.

Podsumowując, wzrost wynagrodzeń w Polsce (a co za tym idzie jednostkowego kosztu pracy) jest nieunikniony, bo wynika z członkostwa Polski w Unii Europejskiej [Belka 2004]. Ze względu na konkurencyjność gospodarki proces ten może utrudniać pozyskiwanie przez Polskę nowych inwestycji zagranicznych typu low-tech. To, co korzystne i daje nadzieję na nowe inwestycje, to utrzymywanie szybszego tempa wzrostu wydajności niż tempa wzrostu jednostkowego kosztu pracy, które powinny czynić Polskę atrakcyjniejszą lokalizacją dla przedsiębiorstw wykorzystujących bardziej zaawansowane technologie (lepiej wykorzystujące wydajność pracy).

\section{Literatura}

Belka M. [2014], Poland's Eurozone Tests, Project Syndicate, http://www.project-syndicate.org/commentary/marek-belka-examines-the-hurdles-that-polish-policymakersmust-surmount-prior-to-euro-membership (dostęp: 20.09.2015).

Blaug M. [1992], The Methodology of Economics, Or, How Economists Explain, Cambridge University Press, Cambridge.

Bossak J. [2001], Międzynarodowa konkurencyjność gospodarki kraju i przedsiębiorstwa. Zagadnienia teoretyczne i metodologiczne [w:] Konkurencyjność gospodarki Polski $w$ dobie integracji z Unia Europejska i globalizacji, red. J. Bossak, W. Bieńkowski, t. I, SGH, Warszawa.

Domański B. [1997], Geografia przedsiębiorstw - niedoceniany nurt badań w polskiej geografii ekonomicznej [w:] Geografia, człowiek, gospodarka, red. B. Domański, Instytut Geografii UJ, Kraków.

Garnick D.H. [1970], Differential Regional Multiplier Models, ,Journal of Regional Science", vol. 10, nr 1, http://dx.doi.org/10.1111/j.1467-9787.1970.tb00033.x.

Jasiński L.J. [2001], Konkurencyjność gospodarek krajów Unii Europejskiej a ewolucja prowadzonych przez nia polityk [w:] Konkurencyjność gospodarki Polski w dobie integracji z Unia Europejska i globalizacji, red. J. Bossak, W. Bieńkowski, t. II, SGH, Warszawa. 
Koszty pracy [2013], NBP, http://www.nbportal.pl/pl/commonPages/EconomicsEntry (dostęp: 15.12.2013).

Kozioł L. [2004], Istota i ocena produktywności, „Zeszyty Naukowe MWSE w Tarnowie", nr 5.

Misala J. [2001], Istota i mierniki międzynarodowej konkurencyjności gospodarki w świetle teorii wymiany międzynarodowej [w:] Konkurencyjność gospodarki Polski w dobie integracji z Unią Europejska i globalizacji, red. J. Bossak, W. Bieńkowski, t. I, SGH, Warszawa.

OECD: Labour Costs [2013], http://stats.oecd.org/glossary (dostęp: 15.12.2013).

Rachwał T., Wiedermann K., Kilar W. [2008], Wydajność i koszty pracy jako czynniki konkurencyjności przemystu Polski na tle Unii Europejskiej w ujęciu regionalnym [w:] Przeksztatcenia regionalnych struktur funkcjonalno-przestrzennych. Europa bez granic - nowe wyzwania, red. D. Ilnicki, K. Janc, Rozprawy Naukowe Instytutu Geografii i Rozwoju Regionalnego Uniwersytetu Wrocławskiego, nr 3, Instytut Geografii i Rozwoju Regionalnego Uniwersytetu Wrocławskiego, Wrocław.

Rybiński K. [2007], Globalizacja w trzech odsłonach. Offshoring - globalne nierównowagi - polityka pieniężna, Difin, Warszawa.

Rydz E., Szymańska W. [2006], Efekty restrukturyzacji słupskiego ośrodka przemysłowego w okresie wdrażania gospodarki rynkowej [w:] Efekty restrukturyzacji polskiej przestrzeni przemysłowej, red. Z. Zioło, T. Rachwał, Prace Komisji Geografii Przemysłu Polskiego Towarzystwa Geograficznego, nr 9, Wydawnictwo Naukowe Akademii Pedagogicznej, Warszawa-Kraków.

Samuelson P.A. [1994], Facets of Balassa-Samuelson Thirty Years Later, „Review of International Economics", vol. 2, nr 3, http://dx.doi.org/10.1111/j.1467-9396.1994. tb00041.x.

Strupczewski G. [2013], Ryzyko i zarzadzanie ryzykiem [w:] Współczesne ubezpieczenia gospodarcze, red. W. Sułkowska, Wydawnictwo Uniwersytetu Ekonomicznego w Krakowie, Kraków.

Wiedermann K. [2007], Regionalne efekty mnożnikowe rozwoju przemysłu motoryzacyjnego w aktywizacji gospodarczej województwa ślaskiego [w:] Rola przedsiębiorczości w aktywizacji gospodarczej, red. Z. Zioło, T. Rachwał, Przedsiębiorczość-Edukacja, nr 3, Zakład Przedsiębiorczości i Gospodarki Przestrzennej, Instytut Geografii, Akademia Pedagogiczna im. Komisji Edukacji Narodowej w Krakowie, WarszawaKraków.

Wpływ inwestorów zagranicznych na rozwój regionalny i lokalny na przykładzie GlaxoSmithKline Pharmaceutical S.A.w Poznaniu [2004], red. T. Stryjakiewicz, Bogucki Wydawnictwo Naukowe, Poznań.

Zioło Z. [2008], Procesy transformacji przemysłowych układów przestrzennych na tle zmieniajacego się otoczenia [w:] Procesy transformacji układów przestrzennych przemysłu na tle zmieniajacego się otoczenia, red. Z. Zioło, T. Rachwał, Prace Komisji Geografii Przemysłu Polskiego Towarzystwa Geograficznego, nr 10, Wydawnictwo Naukowe Akademii Pedagogicznej, Warszawa-Kraków. 


\section{Labour Efficiency, Unit Labour Costs and the Competitiveness of the Polish Economy}

(Abstract)

The study investigates changes in productivity and labour costs in the light of their potential impact on Poland's competitive position in the years 2004-2012. It addresses the following questions: (a) what was the rate of change in labour productivity in Poland in real terms? (b) what was the rate of change in unit labour costs in real terms? (c) were real changes in labour productivity at least as high as the growth rate of unit labour cost? (This would raise the attractiveness of the Polish economy to foreign investors looking to locate production plants), and (d) how do the changes in labour productivity and labour costs in Poland relate to other world economies and what is the position of Poland in this regard in the international arena? With the international comparisons, special emphasis has been placed on Poland relative to the Czech Republic, Slovakia and Hungary as countries with a similar level of economic development and a similar business environment, though Poland was also compared to other countries.

As is clear from the research, labour productivity growth in Poland was higher than the increase in unit labour costs, which should have a positive impact on the country's competitive position. Furthermore Poland is no longer among the countries with the lowest salaries, which means that the current competitiveness is not based solely on cheap labour but on a combination of low labour costs and relatively high labour productivity.

Keywords: labour productivity, unit labour cost, competitiveness, wages, international investments. 